\title{
KESALAHAN PENGGUNAAN BAHASA PADA IKLAN KOMERSIAL MEDIA LUAR RUANG DI KABUPATEN KEDIRI
}

\section{ERROR OF LANGUANGE USE ON OUTDOOR MEDIA COMMERCIAL ADVERTISING IN KEDIRI DISTRICT}

\author{
Ervina Damayanti \\ Universitas Islam Kadiri \\ rvn.damayanti@gmail.com
}

\begin{abstract}
Abstrak
Penelitian ini bertujuan untuk menganalisis kesalahan berbahasa dari segi ejaan dan struktur frasa pada penggunaan bahasa iklan media luar ruang di Kabupaten Kediri. Penelitian ini menggunakan metode kualitatif deskriptif. Wujud data dalam penelitian ini berupa kata-kata, kalimat, dan wacana yang berupa papan nama, baliho, dan spanduk yang terdapat di wilayah Kabupaten Kediri. Teknik pengambilan sampel yang digunakan pada penelitian ini adalah teknik purposive sampling. Dalam hal ini peneliti memilih iklan komersial media luar ruang di tiga wilayah Kabupaten Kediri, yaitu Kecamatan Ngasem, Gurah, dan Pare. Teknik pengumpulan data yang digunakan dalam penelitian ini adalah teknik dokumentasi, catat dan simak. Sementara itu, analisis data yang dilakukan dalam penelitian ini terdiri dari tiga komponen, yaitu pengumpulan data, pengolahan data, dan penarikan kesimpulan. Hasil penelitian ini menunjukkan bahwa masih ada kesalahan bahasa pada penggunaan iklan komersial media luar ruang di Kabupaten Kediri. Kesalahan tersebut berupa kesalahan ejaan dan ketidaktepatan dalam struktur frasa. Kesalahan ejaan terdiri dari kesalahan pada tanda baca, unsur serapan (kata baku/tidak baku), dan penulisan kata. Untuk penggunaan struktur frasa dalam penelitian ini dijumpai adanya papan nama yang menggunakan kosakata bahasa Inggris dengan struktur frasa bahasa Inggris, penggunaan kosakata bahasa Indonesia dan bahasa Inggris, tetapi menggunakan struktur frasa bahasa Inggris, dan yang terakhir penggunaan kosakata bahasa Inggris dan Indonesia, tetapi menggunakan frasa bahasa Indonesia.
\end{abstract}

Kata Kunci: iklan, ejaan, dan struktur frasa

\begin{abstract}
Efforts to dignify indonesian in public bodies, mass media, and on line media continue to be made. One such effort is to hold socialization, coaching to the undertakes in order to put first good and right Indonesian. The study aims to analyze languange errors in terms of spelling and phrase structure on the use of outdoor media advertising languange in Kediri district. This study used descriptive qualitative methods. The data in the study was a word, sentence, and, discourse that was named, a baliho and banner in the district to the Kediri district. The sampling technique used in this study was purposive sanpling. In which case researchers chose the commercial advertisement of outdoor media in the district. There ar three regions selected in the study. The region is considered strategic, crowded and has a high economic level. The subdistrict of Ngasem, Gurah, and Pare. Data collection techniques performed in this study are documentation techniques, and notes, and listening. Meanwhile, the analysis of data found in study consisted of three components that were data collection, data processing, and inference withdrawal. The results of this study suggest that there is still a languange error on the commercial use of outdoor media in Kediri district. The errors in the form of spelling errors and inaccuracies in phrase structure. Spelling error consist of absorption elemental punctuation error (default word), and word writing. For the use of phrase structure in this study encountered the presence of signage using english vocabulary with the structure of english phrases. Use of indonesian vocabulary and english, but using the structure of english phrases. The latter use of english and indonesian vocabulary, but use the phrase indonesian.
\end{abstract}

Keywords: advertising, spelling, phrase structure 


\section{PENDAHULUAN}

Iklan merupakan alat komunikasi yang memiliki kekuatan sangat penting sebagai alat pemasaran yang membantu menjual barang, memberikan layanan, serta gagasan, atau ideide melalui saluran tertentu dalam bentuk informasi yang persuasif (Widyatama 2011). Dalam hal ini iklan bertujuan agar menarik perhatian atau membujuk supaya orang dapat membeli barangnya. Oleh karena itu, bahasa iklan pun dibuat semenarik mungkin supaya dapat memikat konsumennya.

Umumnya iklan bersifat komersial. Namun, iklan juga ada yang bersifat nonkomersil atau iklan layanan masyarakat. Banyak jenis media periklanan untuk digunakan promosi. Media tersebut antara lain media televisi, internet, media cetak, pos langsung, majalah, radio, dan iklan outdor. Iklan outdoor atau media luar ruang adalah iklan yang berukuran besar dipasang di tempat-tempat terbuka, seperti di dalam bus kota, gedung, pagar, tembok dan sebagainya (Susanti 2016). Meskipun media televisi dan digital menjadi primadona untuk promosi, iklan media luar ruang masih diminati oleh pelaku usaha karena dipandang lebih efektif dan efisien dalam mengenalkan jasa konsumen. Salah satu kelebihannya dapat menguasai pasar lokal secara lebih baik yang target konsumennya merupakan masyarakat yang berada di sekitar wilayah pemasangan media tersebut.

Seiring dengan kemajuan informasi, entah sadar atau tidak justru adakalanya iklan jauh dari bahasa yang efektif dan tidak sesuai dengan kaidah berbahasa Indonesia yang benar. Para penggarap iklan menganggap bahwa menggunakan kosakata dari bahasa Indonesia yang telah dibakukan terkesan kaku dan sulit akrab di telinga masyarakat, padahal seperti tertulis pada pasal 36 UUD 451945 yakni "bahasa Negara ialah bahasa Indonesia." Bahasa iklan mempunyai pengaruh kuat dalam penyebarannya kepada masyarakat. Oleh karena itu, siapa pun itu termasuk pembuat iklan harus menjunjung bahasa Indonesia tanpa merusaknya.

Bahasa Indonesia mempunyai kedudukan sebagai bahasa nasional berdasarkan sumpah pemuda 1928 dan sebagai bahasa negara berdasarkan UUD 1945, sedangkan bahasa daerah berkedudukan sebagai bahasa daerah. Fungsi bahasa Indonesia dalam kedudukannya sebagai bahasa nasional adalah 1) Sebagai jati diri bangsa; 2) lambang kebanggan bangsa; 3) Sarana pemersatu berbagai suku bangsa; 4) Sarana komunikasi antardaerah dan antarbudaya daerah. Fungsi bahasa Indonesia dalam kedudukannya sebagai bahasa negara adalah 1) Sebagai bahasa resmi negara; 2) Sarana komunikasi tingkat nasional; 3)Sarana pengembangan kebudayaan nasional; 4) Sarana pengembangan kebudayaan nasional; 5) Sarana transaksi dan dokumentasi niaga; 6) Sarana pengembangan Iptek; 7) Bahasa media massa. Adapun fungsi bahasa daerah 1) Sebagai lambang identitas daerah. 2) lambang kebangsaan nasional 3) Sarana komunikasi dalam keluarga dan masyarakat daerah. 5) Sarana pendukung dan pemerkaya bahasa Indonesia (Balai Bahasa Jawa Timur 2019).

Kedudukan bahasa Indonesia semakin kuat karena pada tahun 2009 Presiden Republik Indonesia dan DPR mengesahkan berlakunya Undang-Undang Republik Indonesia No. 24 tahun 2009, tentang bendera, Bahasa, dan Lambang Negara serta Lagu Kebangsaan Indonesia Raya. Dalam bab III Undang-Undang tersebut terdapat pasal-pasal yang berisi kebijakan bahasa nasional, yaitu pasal 25 sampai dengan pasal 45. Pasal yang 
dijadikan pokok bahasan dalam karangan ini adalah pasal 36 yang terdiri atas 3 ayat, yaitu ayat (1) berbunyi "Bahasa Indonesia wajib digunakan dalam nama geografi di Indonesia"; Ayat (2) menegaskan bahwa "Nama geografi sebagaimana dimaksud pada ayat (1) hanya memiliki satu nama resmi"; Ayat (3) Menyatakan bahwa bahasa Indonesia wajib digunakan untuk nama bangunan atau gedung, jalan, apartemen, atau permukiman, perkantoran, kompleks perdagangan, merk dagang, lembaga usaha, lembaga pendidikan, organisasi, yang didirikan atau badan hukum Indonesia"; dan ayat 4 berisi tentang "Penamaan sebagaimana dimaksud pada Ayat (1) dan Ayat (3) dapat menggunakan bahasa daerah atau bahasa asing apabila memiliki nilai sejarah, budaya, adat istiadat, dan atau keagamaan. Undang-undang nomor 24 tahun 2009 pasal 37 ayat 1 dan 2 menyatakan 1) Bahasa Indonesia wajib digunakan dalam informasi tentang produk barang dan jasa produksi dalam negeri atau luar negeri yang beredar di Indonesia; 2) Informasi sebagaimana dimaksud pada ayat (1) dapat dilengkapi dengan bahasa daerah atau bahasa asing sesuai keperluan. Selain itu UndangUndang nomor 24 tahun 2009 pasal 38 ayat 1 dan 2 menyatakan bahwa 1) Bahasa Indonesia wajib digunakan dalam rambu, petunjuk jalan, fasilitas umum, spanduk, dan alat informasi lain yang merupakan pelayanan umum; 2) Penggunaan bahasa Indonesia sebagaimana dimaksud pada ayat (1) dapat disertai bahasa daerah/bahasa asing (Arifin 2015: 1-23).

Landasan hukum dalam pengutaman bahasa di media luar ruang juga diatur dalam peraturan pemerintah nomor 57 tahun 2014 tentang pengembangan, pembinaan, perlindungan bahasa dan sastra serta peningkatan bahasa Indonesia. kemudian diperkuat oleh Permendagri no. 40/2007 yang isinya bahwa dalam menyelenggarakan otonomi, daerah mempunyai kewajiban melindungi masyarakat, menjaga persatuan, kesatuan, dan kerukunan nasional, serta memelihara keutuhan NKRI dan melestarikan nilai sosial budaya. Dalam konteks itu bahasa nasional/bahasa negara mempunyai peran sebagai sarana komunikasi masyarakat antardaerah dan antarbudaya sekaligus sebagai pengikat masyarakat untuk bersatu, rukun, dan menjaga NKRI (Balai Bahasa Jawa Timur 2019)

Dasar pengutamaan bahasa Indonesia juga diatur dalam Permendagri nomor 40 tahun 2007 pasal 2 yang isinya kepala daerah bertugas melaksanakan 1) Pelestarian dan pengutamaan penggunaan bahasa negara di daerah; 2) Pelestarian dan pengembangan bahasa daerah sebagai unsur kekayaan budaya dan sebagai sumber utama pembentuk kosakata bahasa Indonesia; 3) Sosialisasi penggunaan bahasa negara sebagai pengantar dalam pendidikan/belajar mengajar, forum pertemuan resmi pemerintah dan memerintah daerah, surat menyurat, resmi/kedinasan, dan dalam kegiatan lembaga/badan usaha swasta serta organisasi kemasyarakatan di daerah; 4) Sosialisasi penggunaan bahasa daerah dalam kegiatan pelestarian dan pengembangan seni budaya di daerah (Balai Bahasa Jawa Timur 2019).

Permendagri nomor 40 tahun 2007 pasal 3 juga semakin menguatkan kedudukan bahasa Indonesia, yang isinya dalam melaksanakan tugas kepala daerah 1) Melakukan koordinasi antarlembaga dalam pengutamaan penggunaan bahasa negara atas bahasabahasa lainnya pada berbagai forum resmi di daerah; 2) Menerbitkan petunjuk kepada seluruh aparatur di daerah dalam menerbitkan penggunaan bahasa di ruang publik, termasuk papan nama nama instansi/lembaga/badan usaha/badan sosial, petujuk jalan dan 
iklan, dengan mengutamakan penggunaan bahasa negara; 3) Memberikan fasilitasi untuk pelestarian dan pengembangan bahasa negara dan bahasa daerah; dan 4) Bekerja sama dengan instansi vertikal di daerah yang tugasnya melakukan pengkajian, pengembangan, dan pembinaan bahasa (Balai Bahasa Jawa Timur 2019).

Upaya untuk memartabatkan bahasa Indonesia telah dilakukan. Namun, tantangan tersebut tidak semudah membalikkan telapak tangan. Perkembangan teknologi informasi, pasar bebas dan akulturasi budaya membuat posisi bangsa Indonesia sebagai negara berkembang lebih banyak dipengaruhi oleh negara yang lebih kuat dari segi ekonomi, politik, pertahanan, dan keamanan. Faktanya, walaupun kedudukan bahasa Indonesia lebih kuat di bandingkan bahasa asing, tetapi dalam penyampaian pesan informasi bahasa asing terutama bahasa Inggris cenderung mendominasi. Bahasa Indonesia belum bisa menjadi tuan rumah bagi bangsanya sendiri. Luasnya pengaruh bahasa Inggris terhadap bahasabahasa di dunia semakin mempengaruhi pada semua aspek kehidupan. Salah satu pengaruh tersebut adalah banyaknya iklan media luar ruang yang memakai bahasa asing terutama bahasa Inggris. Pemakaian bahasa asing tidak dilarang, tetapi alangkah lebih bijaknya tidak menjadikan bahasa asing sebagai bahasa utama yang justru tidak baik bagi perjalanan bahasa Indonesia.

Kabupaten Kediri merupakan salah satu Kabupaten di wilayah selatan Provinsi Jawa Timur Indonesia. Berdasarkan pengamatan penulis, tidak sulit menemukan iklan di sepanjang jalan di Kabupaten Kediri. Hampir di setiap jalan terdapat beragam reklame. Penulis melakukan pengamatan mulai dari jalan raya Ngasem Kediri menuju arah selatan, kemudian ke timur sampai Kecamatan Pare hasilnya, terdapat ribuan iklan media luar ruang seperti banner, spanduk, papan nama, papan reklame, umbul-umbul, dll. Reklame tersebut ada yang berizin dan ada yang menyalahi aturan, seperti tidak berizin atau reklame yang dipaku di pohon.

Fokus dalam penelitian ini adalah iklan komersial yang berada di jalan Kecamatan Pare, Ngasem, dan Gurah Kabupaten Kediri. Penulis mengambil tiga tempat tersebut karena Kecamatan Pare merupakan ibu kota Kabupaten Kediri. Di kecamatan tersebut terdapat hotel, swalayan, sekolah, kantor Universitas, kantor polisi, pom bensin, dan terdapat kampung Inggris. Sedangkan alasan penulis mengambil tempat di Kecamatan Ngasem karena Ibu kota Kediri memang berada di Kecamatan Pare, tetapi secara de jure Ibu kota Kediri terletak di Kecamatan Ngasem. Di Kecamatan Ngasem terdapat kantor pemerintahan, seperti kantor Kabupaten Kediri, Kantor Pengadilan dll. hotel, toko, pusat perbelanjaan, restoran, pom bensin juga ada. Di Kecamatan Ngasem terdapat monumen Simpang Lima Gumul yang merupakan ikon Kabupaten Kediri. Adapun Kecamatan Gurah merupakan Kecamatan yang letaknya berada di tengah-tengah Kabupaten Kediri yang letaknya tidak jauh dari Kecamatan Ngasem.

Pada saat ini pemakaian bahasa asing terutama bahasa Inggris banyak digunakan dalam media iklan luar ruang di Kabupaten Kediri, seperti pada papan nama, reklame, baliho, spanduk dll. Menurut pelaku usaha bisnis di Kediri, penggunaan bahasa Inggris dapat memberikan rasa gengsi yang tinggi, lebih menarik, lebih berkelas, dan dapat memberikan nuansa berbeda sehingga diharapkan dapat memberikan keuntungan bagi mereka. Namun, penggunaan bahasa asing tersebut ternyata tidak diimbangi oleh 
pengetahuan berbahasa secara benar, seperti penggunaan kosakata bahasa Indonesia, tetapi memakai struktur nomina bahasa asing (MD) contohnya Aulia Butik. Selain penggunaan struktur kata bahasa Inggris yang salah, iklan komersial pada media luar ruang di Kediri masih dijumpai kesalahan berupa ejaan, contohnya ketidaktepatan dalam penggunaan kata depan /di/ seperti kata di depan ditulis /didepan/ dan banyak dijumpai kata tidak baku.

Penelitian ini dimaksudkan untuk menganalisis kesalahan berbahasa pada penulisan iklan media luar ruang di wilayah Kabupaten Kediri. Objek penelitian ini adalah penulisan pada papan nama, baliho, dan spanduk yang ada di Kabupaten Kediri. Penelitian tentang kesalahan bahasa sudah banyak dilakukan, tetapi penelitian kesalahan bahasa pada iklan media luar ruang di Kabupaten belum pernah diteliti. Upaya pembinaan, sosialisasi terhadap bahasa di ruang publik belum pernah dilakukan oleh pemerintah daerah, Setahu penulis sosialisasi bahasa untuk media luar ruang hanya pernah dilakukan di Kota Kediri. Penulisan ini juga diharapkan dapat memberikan informasi tentang penggunaan bahasa Indonesia sesuai kaidah yang berlaku, terutama dari segi struktur frasa dan ejaan khususnya bagi masyarakat Kota Kediri, sehingga diharapkan ada perbaikan dan jika perlu ada peraturan daerah/peraturan bupati/tentang pengutamaan bahasa Indonesia. Diharapkan ke depan Kabupaten Kediri menjadi Kabupaten dengan predikat terbaik, terutama terkait penulisan bahasa media luar ruang. Atas dasar tersebut, penulis mengambil judul Penelitian "Analisis Kesalahan pada penggunan Iklan Media Luar di Kabupaten Kediri."

\section{METODE PENELITIAN}

Metode dalam penelitian ini adalah metode deskriptif kualitatif. Variabel data berupa kalimat, yaitu berupa kesalahan penggunaan bahasa pada media luar ruang di Kabupaten Kediri.

Penelitian terbatas pada iklan yang di dalamnya terdapat kesalahan berbahasa. Teknik pengambilan sampel atau sampling yang digunakan pada penelitian ini adalah purposive sampling. Sampel diambil ditiga tempat yaitu kecamatan Ngasem, Gurah, dan Pare Kediri. Ketiga kecamatan tersebut merupakan pusat ekonomi dan pemerintahan, serta merupakan tempat strategis. Objek dalam penelitian ini berupa kesalahan bahasa pada iklan media luar yang ada di papan nama, spanduk, baliho.

Teknik pengumpulan data yang digunakan dalam penelitian ini adalah teknik dokumentasi dan teknik catat. Teknik dokumentasi diperoleh dengan bantuan kamera smartphone untuk mendokumentasikan data sebagai suatu bukti nyata. Teknik catat dilakukan dengan melakukan pencatatan kesalahan berbahasa baik ejaan maupun struktur kata pada kartu data yang kemudian dilanjutkan klasifikasi (Sudaryanto 1993). 
Tabel 1 Contoh Kartu Data

\begin{tabular}{ll}
\hline Nomor kartu data & $: 01$ \\
Jenis Iklan & $:$ Toko pakaian \\
Kode Kata & $:$ AB \\
Media iklan & $:$ Papan nama \\
Jenis kesalahan & $: \sqrt{ }$ \\
1. Ejaan & $:$ Penggunaan kata depan \\
Kesalahan & \\
2. Struktur kata & \\
Kesalahan & \\
\hline
\end{tabular}

Kartu data berisi nomor data, kode data. Data iklan akan diidentifikasi berdasarkan unsur kesalahannya, meliputi kesalahan ejaan atau kesalahan struktur frasa

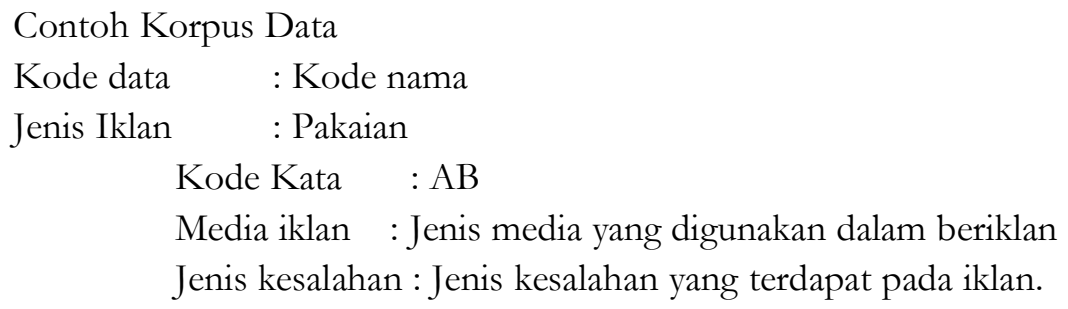

Secara garis besar analisis data yang pertama dilakukan adalah tahap persiapan dan observasi, kemudian dilanjutkan mencari referensi dari buku atau jurnal dari penelitian sebelumnya yang dianggap sesuai dengan data permasalahan yang penulis temukan. Setelah masalah teridentifikasi dasar-dasar studi data ditemukan, tahap berikutnya mengadakan pengumpulan data dari observasi langsung melalui pengamatan, pendokumentasian, dan wawancara. Setelah data terkumpul data tersebut diolah berdasarkan kesalahan berbahasa pada penulisan iklan media luar ruang yang ada di Kabupaten Kediri. Tahap berikutnya menjelaskan bentuk kesalahan berbahasa Indonesia. Langkah terakhir adalah evaluasi terhadap hasil pengidentifikasian dan pengklasifikasian untuk mendapatkan kesimpulan akhir. Garis besar analisis kesalahan berbahasa adalah mengumpulkan data, mengidentifikasi data, dan menjelaskan kesalahan data (Henry dan Djagu tarigan 2011).

\section{Bagan 1 Tahap Penelitian}




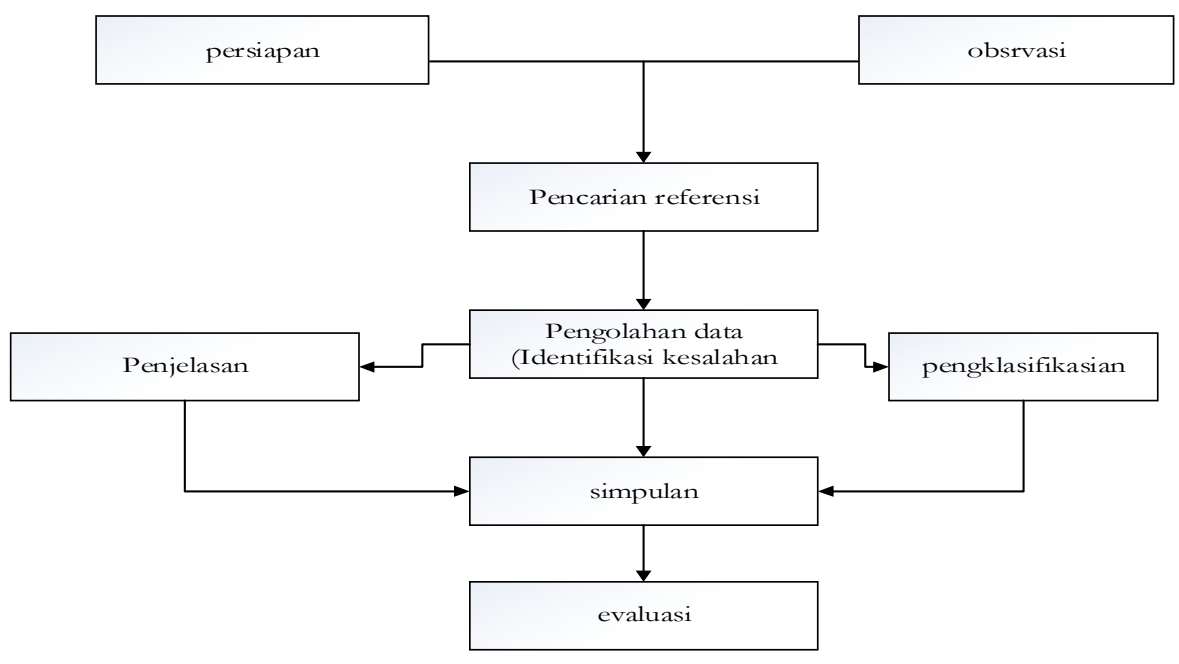

\section{HASIL DAN PEMBAHASAN}

Kesalahan berbahasa adalah penggunaan bahasa, baik secara lisan maupun tertulis yang menyimpang dari faktor-faktor komunikasi atau menyimpang dari norma kemasyarakatan dan menyimpang dari kaidah tata bahasa Indonesia yang meliputi kata, kalimat, dan kesalahan penggunaan ejaan yang menyimpang dari sistem ejaan yang sudah ditetapkan di dalam Pedoman Ejaan Umum Bahasa Indonesia (Setyowati 2010). Menurut Tarigan (dalam Setyowati 2010) kesalahan berbahasa Indonesia berdasarkan tataran linguistik yaitu berupa kesalahan fonologi, morfologi, sintaksis (frasa, klausa, kalimat), semantik, dan wacana.

Fokus penelitian ini adalah kesalahan iklan berdasarkan ejan dan struktur frasa pada iklan media luar ruang Kediri. Kesalahan ejaan ialah kesalahan menuliskan kata atau menggunakan tanda baca (Tarigan 2011). Penentuan kesalahan ejaan dalam penelitian ini, menggunakan buku Pedoman Umum Ejaan Bahasa Indonesia berdasarkan PERMENDIKBUD No. 50 tahun 2015 (Rahmadi 2017) dan Kamus Besar Bahasa Indonesia edisi V. Berdasarkan pedoman di atas, jenis kesalahan yang akan diteliti yaitu pemakaian huruf, penulisan huruf kapital dan huruf miring, penulisan kata, penulisan unsur serapan, dan pemakaian tanda baca.

\section{Kesalahan Ejaan}

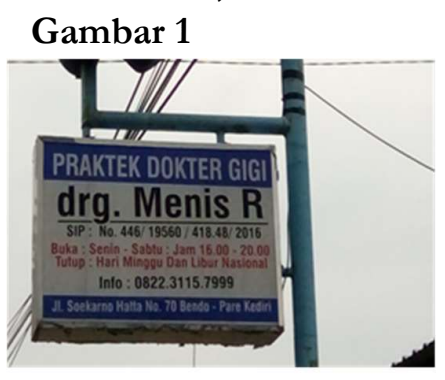

\section{Penulisan yang salah \\ PRAKTEK \\ Penulisan yang benar PRAKTIK}

Lokasi papan nama di atas berada di desa Bendo Kecamatan Pare Kabupaten Kediri. Foto diambil pada hari Selasa tanggal 23 Juli 2019. Papan nama ini terletak di depan SMPN 
1 Pare Kabupaten Kediri. Lokasi tersebut juga berdekatan dengan beberapa kampus, dan sekolah swasta lainnya.

Kata praktek pada data di atas adalah kata yang tidak baku. Kata tersebut merupakan kata yang menyimpang dari kebahasaan yang berlaku. Penyesuian akhiran '-ic; dalam bahasa Inggris atau -isch dalam bahasa Belanda menjadi '-ik' dalam bahasa Indonesia. Praktik adalah kata serapan yang tepat. Oleh karena itu, di dalam KBBI tidak ditemukan kata praktek, tetapi adanya kata praktik. Kata praktik menurut KBBI artinya pelaksanan pekerjaan (tentang dokter, pengacara, dan sebagainya). Dari kata praktik, diturunkan kata praktikan (orang yang sedang melakukan praktik) dan praktikum (kegiatan yang berkaitan dengan praktik atau percobaan).

\title{
Gambar 2
}

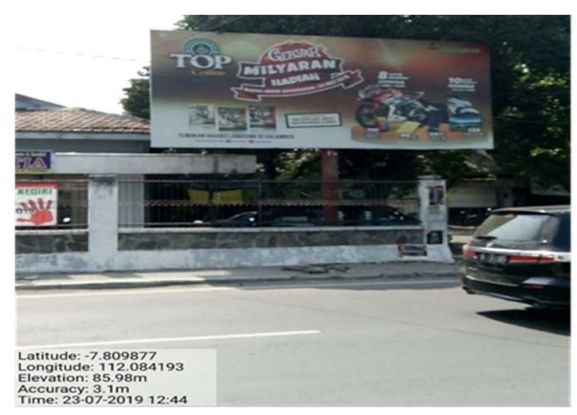

\author{
Penulisan yang salah \\ Milyar \\ Penulisan yang Benar \\ Miliar
}

Iklan niaga di atas teletak di jalan raya Gurah Kabupaten Kediri. Gambar ini diambil pada hari Selasa tanggal 23 Juli 2019. Iklan ini berada di depan pasar Gurah.

Kata milyar merupakan kata tidak baku. Di dalam KBBI tidak ditemukan kata milyar, tetapi yang ada kata miliar. Penyebab kata tidak baku dari kata milyar adalah adanya penggantian huruf vokal dengan huruf konsonan (Miftahudin 2011). Contoh penggantian huruf vokal dengan huruf konsonan lainnya adalah kata mulia menjadi mulya, psikologi menjadi psykologi. Kata miliar berasal dari bahasa Belanda, miljard dan dari bahasa Prancis, miliard, adalah sebuah bilangan yang menunjukkan 1000 juta, atau atau $109=$ 1.000.000.000. Penyerapan kata miljard atau miliard melalui proses adaptasi, yaitu proses diserapnya bahasa asing dengan cara pemakai bahasa tersebut mengambil kata bahasa asing, tetapi ejaan dan cara penulisannya berbeda juga disesuaikan dengan aturan bahasa Indonesia. Proses diserapnya bahasa asing dengan cara pemakai bahasa tersebut mengambil kata bahasa asing, tapi ejaan dan cara penulisannya berbeda juga disesuaikan dengan aturan bahasa Indonesia.

\section{Gambar 3}

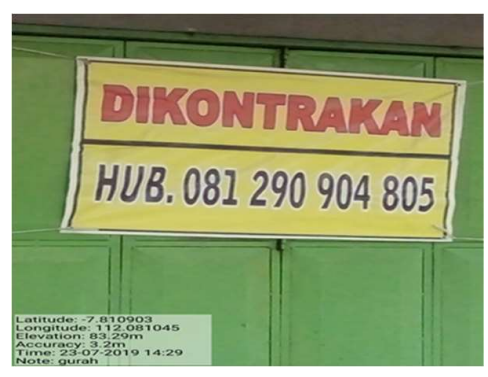

Penulisan yang salah : dikontrakan

Penulisan yang benar: dikontrakkan 
Iklan ini berada di jalan Gurah Kabupaten Kediri. Iklan diambil pada hari Selasa tanggal 23 Juli 2019. Kata dikontrakan pada penulisan iklan di atas salah. Kata kontrakan berasal dari kata dasar 'kontrak' mendapat awalan di- dan akhiran -an, padahal tidak ada konfiks 'di-an'. Kata 'kontra' menurut KBBI mempunyai arti dalam keadaan tidak setuju, dalam keadaan melawan, menentang. Ketika kata kontra diberi awalan -di dan akhiran-kan 'di-kontra-kan' maka artinya memiliki makna menyebabkan atau membuat jadi kontra, padahal yang dimaksud oleh pemasang tulisan adalah menawarkan tempat atau rumah.

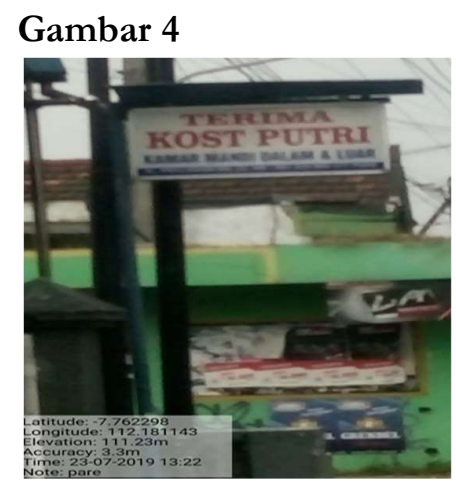

\section{Penulisan yang salah KOST \\ Penulisan yang benar KOS}

Iklan ini berada di Jalan raya Pare Kabupaten Kediri. Gambar diambil pada hari Selasa tanggal 23 Juli 2019. Kata "kost" berasal dari bahasa Belanda "in de kost" yang artinya "makan di dalam" atau tinggal dan ikut makan" di dalam rumah tempat tinggal.

Dalam masa penjajahan, bangsa Belanda ataupun bangsa Eropa umumnya mendapat status sangat terpandang dan memiliki kedudukan tinggi dalam strata sosial di masyarakat, terutama di kalangan pribumi. Orang-orang yang bukan orang Belanda dan berpandangan non-tradisional menganggap perlunya anak mereka bersikap "seperti layaknya" orang Belanda. Dengan membayar sejumlah uang tertentu sebagai jaminan, anaknya diperbolehkan untuk tinggal di rumah Belanda yang mereka inginkan, dengan beberapa syarat yang sudah diperhitungkan, dan resmilah si anak angkat sebagai anak angkat oleh keluarga Belanda tersebut. Setelah tinggal serumah dengan keluarga Belanda, selain diperbolehkan makan dan tidur di rumah tersebut, si anak tetap dapat bersekolah dan belajar menyesuaikan diri dengan gaya hidup keluarga tempat ia menumpang. Inti dari in de kost adalah anak mampu mandiri sesuai dengan tradisi tempat ia tinggal. Seiring berjalannya waktu dan berubahnya zaman, khalayak umum di Indonesia menyebut istilah "in de kost" dengan menyingkatnya menjadi "kost" saja (sumber wikipedia)

Kata "in de kost" kemudian diserap oleh bahasa Indonesia menjadi "in de kos. Oleh karena itu, kata yang benar adalah in de kos atau kos. Menurut KBBI kos artinya tinggal di rumah orang lain dengan atau tanpa makan (dengan membanyar setiap bulan) 


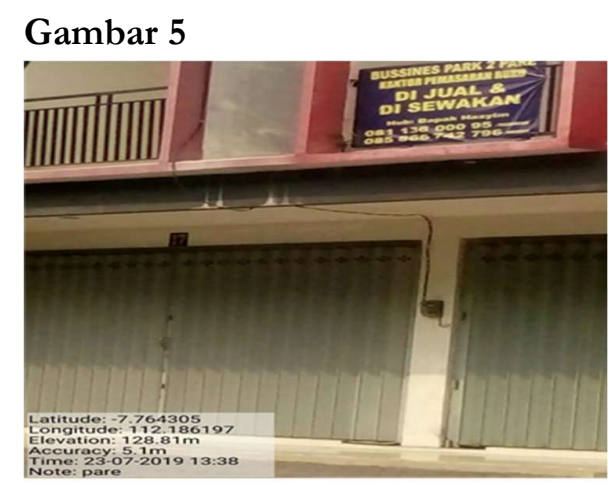

\author{
Penulisan yang salah \\ DI JUAL, DI SEWAKAN \\ Penulisan Yang Benar \\ DIJUAL, DISEWAKAN
}

Iklan tersebut diambil hari Selasa tanggal 23 Juli 2019. Iklan terletak di ruko Jalan Dr. Soetomo dekat dengan masjid agung Pare. Pada iklan di atas terdapat kesalahan kata depan "di" pada kata "di jual" dan kata "di sewakan". Penulisan kata hubung di sering disepelekan. Penulisan kata yang benar adalah "dijual" dengan keterangan tidak perlu menggunakan spasi antara kata di dengan kata berikutnya, yaitu "jual”. Hal tersebut sesuai dengan ejaan bahasa indonesia yang menjelaskan bahwa kata depan di, ke, dari ditulis terpisah dari kata yang mengikutinya, kecuali di dalam gabungan kata yang dianggap lazim dianggap satu kata contohnya, daripada dan kepada.

Ada dua "di" dalam dua kalimat. "di" yang pertama menunjukkan tempat, yang harus dituliskan terpisah dari kata yang menunjukkan tempat. "di” yang kedua merupakan sebuah awalan untuk sebuah kata kerja pasif yang harus digabungkan pada kata yang diawalinya. Jadi, kata depan "di" yang ada di gambar dia atas harus digabung menjadi "dijual" karena kata jual merupakan kata kerja jika digabungkan dengan kata depan "di”"maka kata "jual” itu menjadi kata kerja pasif. Sedangkan untuk kata disewakan / di/ tidak menyatakan tempat sesuai EBI penulisannya dirangkai, yaitu disewakan.

\title{
Gambar 6
}



\author{
Penulisan yang benar \\ fotokopi, fotografi \\ ATAU \\ fotocopy, fotography, video shooting \\ dimiringkan.
}

Iklan ini terletak ini Jalan Seruji Kecamatan Gurah Kabupaten Kediri, gambar diambil hari Selasa tanggal 23 Juli 2019. Iklan berada di dekat SMP Negeri 1 Gurah Kediri dan beberapa sekolah lainnya. Kesalahan penulisan kata fotocopy sering kita jumpai di tempat fotokopi yang tersebar di sepanjang jalan, maupun di tempat perkantoran. Nyaris penulis belum pernah menemukan penulisan kata fotokopi secara benar. Huruf 'ph' (bahasa Inggris) diserap menjadi ' $\mathrm{f}$ dalam bahasa Indonesia. Huruf 'c' (bunyi k) diikuti vokal o menjadi ' $\mathrm{k}$ ' dan ' $\mathrm{y}$ ' menjadi i, sehingga kata fotocopy sudah diserap bahasa Indonesia menjadi 
fotokopi. Hal ini juga berlaku pada kata fotography di atas yang seharusnya menjadi fotografi. Sebaliknya kata scan dan print video shooting belum diserap oleh bahasa Indonesia. Sesuai ejaan bahasa Indonesia kata scan dan print sebaiknya kata tersebut dimiringkan. Jadi, alternatif pembenaran, sebaiknya menggunakan kata fotokopi, fotografi karena memang kata tersebut sudah ada di bahasa Indonesia. Alternatif kedua jika berpanduan EBI kata tersebut kata fotocopy, fotography harus dimiringkan jika menggunakan bahasa Inggris.

\section{Gambar 7}

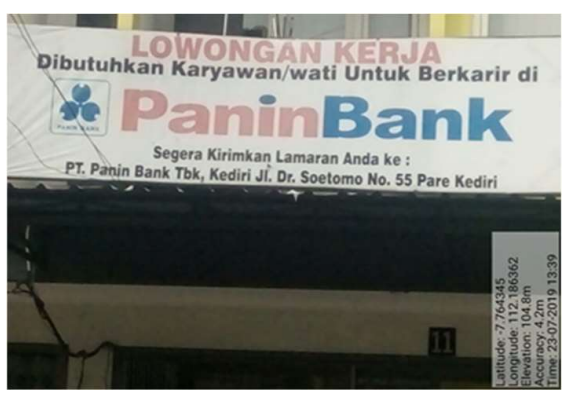

\section{Penulisan yang salah : (PT. ) (Karir) Penulisan yang benar : (PT), (Karier)}

Iklan papan nama milik instansi bank ini berada di halaman di ruko jalan Dr. Soetomo Pare, iklan diambil pada Selasa tanggal 23 Juli 2019. Perseroan terbatas atau biasa disingkat PT penulisannya harus tidak diikuti tanda titik setelah huruf "T". Ini sejalan dengan penjelasan contoh yang tertera dalam bagian singkatan atau akronim. Dalam PUEBI singkatan nama resmi lembaga pemerintahan dan ketatanegaraan badan atau organisasi, serta nama dokumen resmi yang terdiri atas gabungan huruf awal kata ditulis dengan huruf kapital dan tidak diikuti tanda titik. Kesalahan berikutnya adalah kata karir. Kata karir tidak ditemukan di KBBI, tetapi yang ditemukan adalah kata karier. Dengan demikian, yang baku dari kata tersebut adalah karier. Kata karier berasal dari kata Belanda carriere yang artinya perkembangan dan kemajuan dalam pekerjaan seseorang. Ini juga bisa beraarti jenjang dalam sebuah pekerjaan baru. Kata karier sering ditulis karir dikategorikan sebagai kesalahan fonologi karena penyebabnya adanya penyederhanaan deret kata (Miftahudin 2014 ). Contoh karier menjadi karir, varietas menjadi varitas. Selain itu frasa di atas mengalami penyimpangan dalam struktur frasa. Di Indonesia berlaku hukum DM, bukan MD kecuali kata tertentu, frasa di atas seharusnya bank Panin bank sebagai (D) nomina inti, Panin sebagai (M) menerangkan. Struktur frasa di atas mengikuti struktur bahasa Inggris MD Panin sebagai menerangkan (M) bank sebagai nomina inti (D). Jadi, yang benar adalah bank Panin

\section{Struktur Frasa}

Selain menganalisis kesalahan berbahasa dari segi ejaan, penulis juga menganalisis struktur frasa. Fenomena penulisan papan nama media luar dengan menggunakan kosakata bahasa asing, khususnya bahasa Inggris marak dilakukan. Umumnya pemakaian kosakata bahasa Inggris lebih berkelas, elegan, dan menarik. Berdasarkan pengamatan penulis, beberapa badan usaha, seperti perumahan mewah di Kabupaten Kediri sudah menggunakan bahasa Indonesia. Contohnya perumahan Kwadungan Indah dll. ini membawa dampak positif karena dapat mengangkat bahasa Indonesia semakim 
bermartabat. Walau demikian masih banyak dijumpai badan usaha seperti, restoran, hotel, perumahan yang memakai bahasa asing.

Pada umumnya yang sering menggunakan bahasa Inggris pada iklan media luar ruang adalah papan nama atau badan usaha. Pemakaian bahasa Inggris pada papan nama cenderung memakai frasa nomina. Frasa nomina adalah frasa yang dibentuk dari kata benda nomina. Sebagai inti frasa, nomina menduduki bagian utama, sedangkan pewatas berada di muka atau dibelakangnya (Alwi, 1998). Dalam membentuk frasa umumnya pokok utama yang diterangkan diletakkan di depan, sedangkan keterangan atau penjelasannya diletakkan sesudah unsur pokok itu. Inilah yang disebut dengan hukum DM.

Alisjahbana (dalam Prasetyo)1 mengungkapkan bahwa hukum DM menyatakan bahwa yang diterangkan diletakkan di depan, sedangkan keterangan atau penjelasan diletakkan sesudahnya. Di dalam bahasa Indonesia tidak selalu berhukum DM, ada pengecualian-pengecualian tertentu. 1) beberapa jenis kata bantu dan kata keterangan, misalnya akan, lagi, kurang, makin, lebih, terlalu, amat, sedang, susah, dan sebagainya. Misalnya sudah mekar: sudah (M) mekar (D) hukum D-M; 2) kata bilangan, misalnya sebuah, sebutir, sebiji, stas, sebatang, sehelai, satu, dua, tiga, dan sebagainya. Contoh: sebuah jeruk: sebuah (M)- jeruk (D), Berlaku hukum M-D (berapa jeruk); 3) kata depan: misalnya: di, ke, dari, atas, kepada dan sebagainya. Contoh: dari Medan: dari (M) Medan (D). Selain pengecualian tersebut, tidak ditemukan pengecualian yang lain di DM. Ada kalanya untuk menghindari terjadinya penyimpangan atau pelanggaran terhadap peraturan yang berlaku (hukum DM). Gabungan dua kata yang terpisah disatukan penulisannya sehingga menjadi satu kata, misalnya frasa pasaca sarjana : pasca (M), berlaku hukum DM ditulis pascasarjana sehingga tidaka ada masalah hukum.

Hukum DM merupakan salah satu pembeda antara bahasa Indonesia dengan bahasa rumpun Indo-Eropa, seperti bahasa Belanda dan Inggris. Struktur frasa nomina berbahasa

\section{Gambar 8}

\begin{tabular}{|l|l|} 
Pembenaran: Seharusnya di atas kata \\
berbahasa Inggris ada kata bahasa \\
Indonesia, bukan semua kata \\
menggunakan bahasa Inggris.
\end{tabular}

\footnotetext{
${ }^{1}$ Signage In and T H E District, 'PENYIMPANGAN STRUKTUR FRASA BAHASA INDONESIA'.
} 


\title{
Tabel 1
}

Pilihan Kata dan Struktur Bahasa Inggris pada Gambar 8 sebagai berikut

\begin{tabular}{lllll}
\hline $\begin{array}{l}\text { Nama } \\
\text { nama }\end{array}$ & papan & Lokasi & Diterangkan & Menerangkan \\
\hline $\begin{array}{l}\text { Pride } \\
\text { Kitchen }\end{array}$ & Coffe & Katang Ngasem & Pride & Coffe Kitchen \\
\hline
\end{tabular}

Papan nama di atas adalah papan nama milik sebuah kafe yang terletak di jalan raya Katang Kecamatan Ngasem Kediri. Letak papan iniberada di sebelah barat Kantor Kabupaten Kediri. Secara struktur frasa penulisan tersebut tidak salah karena frasa Inggris berhukum (MD). Dalam hal ini Pride berfungsi menerangkan (M) dengan nomina inti coffe kitchen. Bahasa asing, khususnya bahasa Inggris boleh saja digunakan oleh pelaku usaha, tetapi seharusnya penulisan bahasa Indonesia juga ada karena sudah jelas bahwa dalam Undang-Undang bahasa Indonesia wajib digunakan untuk nama bangunan atau gedung, jalan, apartemen, atau pemukiman atau permukiman, perkantoran, kompleks, perdagangan, merk dagang, lembaga usaha, lembaga pendidikan, organisasi yang didirikan atau dimiliki oleh warga negara Indonesia yang berbadan hukum. Aturan tersebut dipertegas oleh amanat Permendagri nomor 40 tahun 2007 bahwa menerbitkan petunjuk kepada seluruh aparatur daerah dalam menerbitkan penggunaan bahasa di ruang publik termasuk papan nama instansi/lembaga badan usaha/badan sosial/ petunjuk jalan dan iklan, dengan mengutamakan penggunaan bahasa negara. Menggunakan bahasa asing boleh saja, tetapi tetap mengutamakan bahasa Indonesia dengan menuliskan juga bahasa Indonesia di atas tulisan bahasa Inggris tersebut.

Beberapa papan nama atau badan usaha mennggunakan frasa bahasa Indonesia dengan benar (DM), tetapi menggunakan bahasa gaul misalnya warunk, waroeng. Berikut salah satu gambar dari papan nama

\section{Gambar 10}

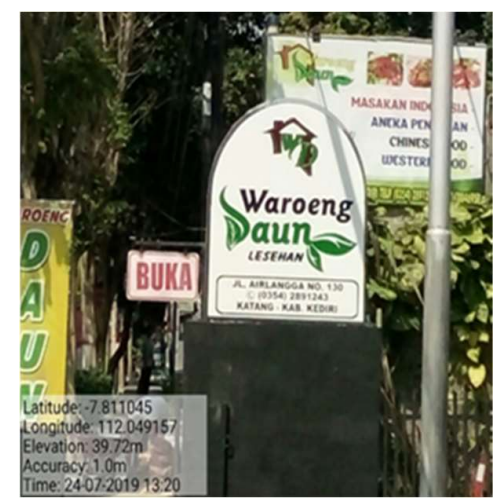

\author{
Kesalahan : Waroeng Daun \\ Pembenaran: Warung Daun
}

Letak restoran atau warung pada gambar di atas berada di Jalan raya Katang Kecamatan Ngasem Kabupaten Kediri. Sebenarnya pemilihan bahasa dalam badan usaha ini bagus, mengutamakan bahasa Indonesia, bukan nama keinggris-inggrisan seperti pada restoran umumnya. Secara frase sudah benar (DM) warung sebagai nomina inti /D/ dan Daun berfungsi menerangkan /M/pemilihan bahasa pada kata woroeng supaya terlihat 
berbeda dan menarik, tetapi kembali lagi kata yang baku adalah warung bukan waroeng. Ejaan ini menggunakan ejaan lama yaitu ejaan van ophuisen pada masa itu huruf $/ \mathrm{u} /$ adalah /oe/. Untuk saat ini ejaan yang berlaku adalah ejaan bahasa Indonesia dan sebaiknya tidak perlu menggunakan huruf vokal /oe/, tetapi ikuti aturan ejaan sekarang dengan mamakai huruf /u/.

Gambar 11 dan 12

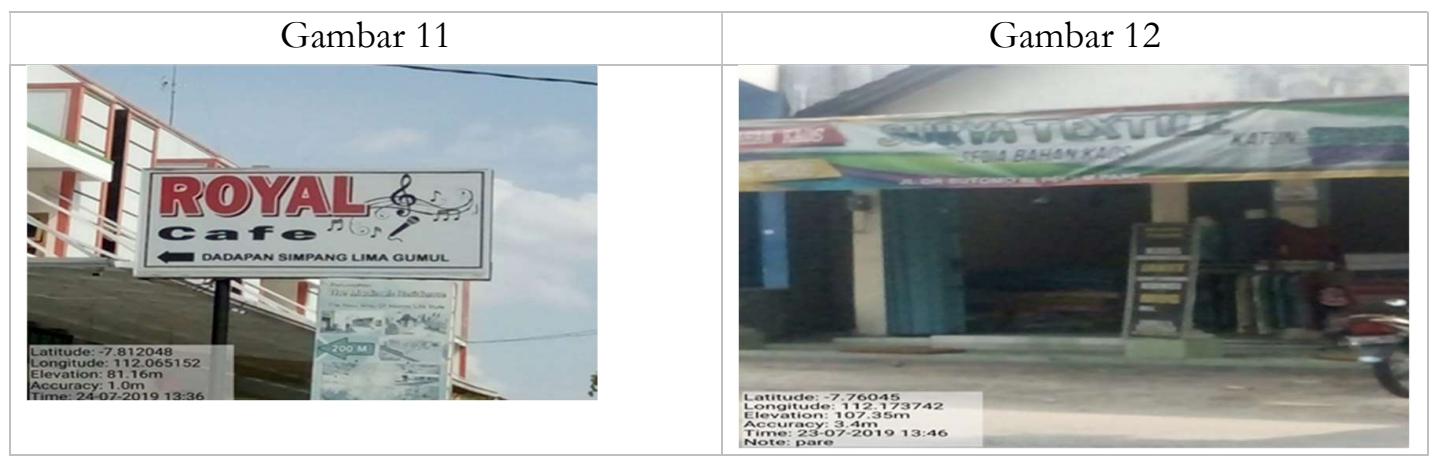

Sesuai gambar di atas beberapa papan nama di Kediri menggunakan kosakata bahasa Indonesia dan bahasa Inggris dengan struktur nomina bahasa Inggris. agar lebih jelas berikut data ditampilkan dalam bentuk tabel berdasarkan gambar di atas.

\section{Tabel 2}

Pilihan Kata Bahasa Indonesia dan Bahasa Inggris serta Berstruktur Bahasa Inggris (MD)

\begin{tabular}{llll}
\hline No. & Nama badan usaha & Diterangkan & Menerangkan \\
\hline 1. & Royal Cafe & Royal & Cafe \\
\hline 2. & Surya Textile & Surya & Textile \\
\hline
\end{tabular}

Gambar 11 terletak di jalan raya Ngasem Kabupaten Kediri, sedangkan gambar 12 terletak di jalan raya Pare Kediri. Papan nama gambar 11 tersebut terletak di dekat simpang lima gumul yang merupakan kawasan ramai. Adapun gambar 12 terletak di dekat perempatan Monumen Garuda Pare Kediri. Penulisan Royal Cafe, Surya Tekstil merupakan frasa perpaduan bahasa Indonesia dan Inggris. Royal, surya merupakan bahasa Indonesia, sedangkan cafe, dan textile merupakan bahasa Inggris. Penulisan frasa tersebut tidak mengikuti hukum DM karena memang cafe, textile merupakan bahasa Inggris. ada dua alternatif pembenaran Agar penulisannya sesuai dengan kaidah bahasa Indonesia kata cafe diganti kafe dan kata textile diganti kata tekstil karena memang kata-kata tersebut sudah ada padanannya pada bahasa Indonesia. Alternatif kedua adalah dengan menyertakan bahasa Indonesia di atas nama bahasa Inggris. berikut tabel alternatif pembenarannya

Tabel 3

\begin{tabular}{|c|c|c|c|}
\hline \multirow[t]{2}{*}{ No. } & \multirow{2}{*}{$\begin{array}{c}\text { Nama badan } \\
\text { usaha }\end{array}$} & \multicolumn{2}{|c|}{ Alternatif Pembenaran } \\
\hline & & $\begin{array}{l}\text { Pemakaian bahasa } \\
\text { Indonesia }\end{array}$ & $\begin{array}{c}\text { Pemakaian bahasa Indonesia } \\
\text { dan bahasa Inggris }\end{array}$ \\
\hline 1. & Surya Textile & Tekstil Surya & Tekstil Surya (Surya Textile) \\
\hline 2. & Royal Cafe & Kafe Royal & Kafe Royal \\
\hline
\end{tabular}




\section{(Royal Cafe)}

Berikutnya beberapa papan nama menggunakan kosakata bahasa Indonesia, tetapi memakai struktur nomina bahasa Inggris (MD). Berikut gambar sekaligus tabelnya:

Tabel 4
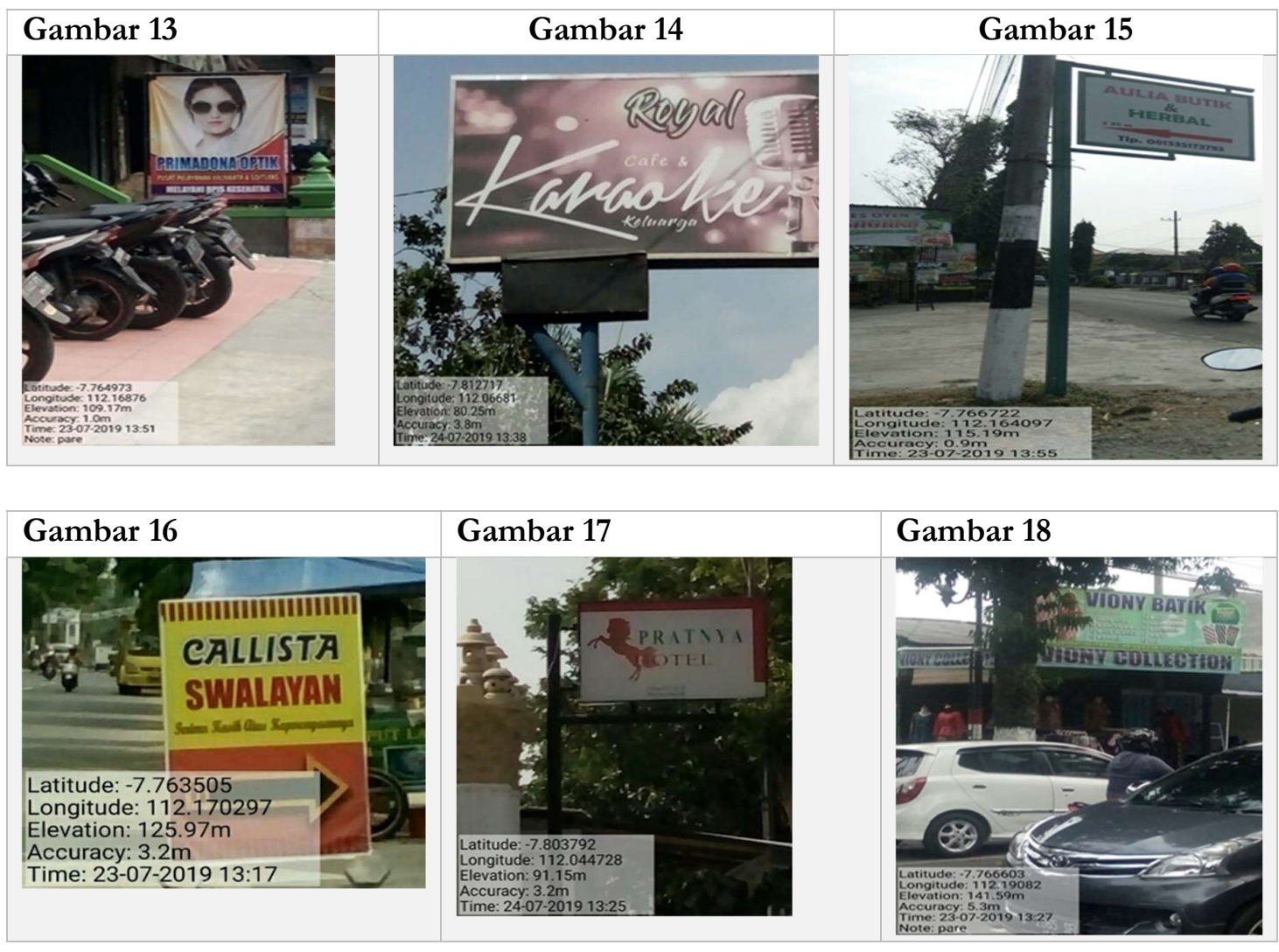

Dari sekian iklan media luar ruang, penulis menemukan bahasa dengan struktur frasa yang salah yang mendominasi adalah papan nama badan usaha yang memakai kosakata bahasa Indonesia, tetapi memakai pola struktur nomina bahasa Inggris (MD). Gambar di atas hanya sedikit contoh kesalahan yang mewakili kesalahan frasa tersebu. Ini jelas bertentangan struktur frase yang digunakan bahasa Indonesia (MD). Ini artinya efek membanjirnya bahasa asing, khususnya bahasa Inggris membuat masyarakat terpengaruh, bahkan beberapa pelaku usaha kurang paham tentang penggunaan frasa bahasa Inggris dan frasa bahasa Indonesia yang benar. Pada akhirnya ketumpangtindihan bahasa asing dan Indonesia semakin membuat kacau bahasa. Berikut tabel penjelasan frasa gambar di atas, sekaligus pembenarannya. 
Tabel 5

Pilihan Kata Bahasa Indonesia, tetapi Memakai Unsur Bahasa Inggris (DM)

\begin{tabular}{clllll}
\hline No. & $\begin{array}{l}\text { Nama badan } \\
\text { usaha }\end{array}$ & letak & $\begin{array}{l}\text { Diterangkan } \\
(\mathbf{D})\end{array}$ & $\begin{array}{l}\text { Menerangkan } \\
\mathbf{( M )}\end{array}$ & Pembenaran \\
\hline $\mathbf{1 .}$ & $\begin{array}{l}\text { Primadona } \\
\text { Optik }\end{array}$ & Pare & Primadona & Optik & $\begin{array}{l}\text { Optik } \\
\text { Primadona }\end{array}$ \\
\hline $\mathbf{2 .}$ & $\begin{array}{l}\text { Royal } \\
\text { Karaoke }\end{array}$ & Ngasem & Royal & Karaoke & Karaoke Royal \\
\hline $\mathbf{3 .}$ & Aulia Butik & Pare & Aulia & Butik & Butik Aulia \\
\hline $\mathbf{4 .}$ & $\begin{array}{l}\text { Callista } \\
\text { Swalayan }\end{array}$ & Gurah & Calista & Swalayan & Swalayan Calista \\
\hline $\mathbf{5 .}$ & $\begin{array}{l}\text { Pratynya } \\
\text { Hotel }\end{array}$ & Ngasem & Pratnya & Hotel & Hotel Pratynya \\
\hline $\mathbf{6 .}$ & Viony Batik & Pare & Viony & Batik & Batik Viony \\
\hline
\end{tabular}

Penemuan berikutnya adalah menggunakan kosakata bahasa Inggris dan bahasa Indonesia, tetapi memakai struktur frasa bahasa Inggris. berikut tabel beserta contoh gambarnya:

\section{Tabel 6}

Pilihan Kata Bahasa Inggris dan Indonesia serta Berstruktur Bahasa Indonesia (DM)

\begin{tabular}{lll}
\hline Papan Nama & Diterangkan & Menerangkan \\
\hline Massage Tradisional & Massage & Tradisional \\
\hline Gallery Jati Murni & Gallery & Jati Murni \\
\hline Cafe Srikandi & Cafe & Srikandi \\
\hline
\end{tabular}

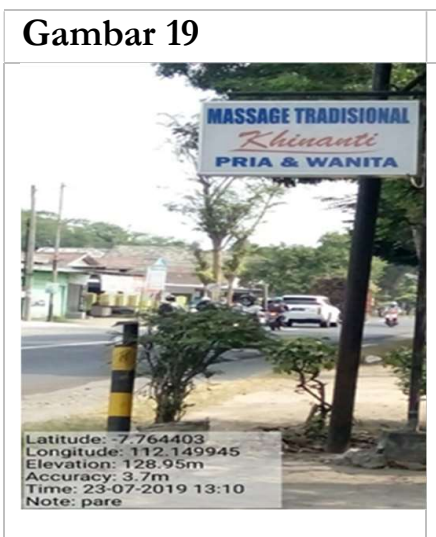

Gambar 20

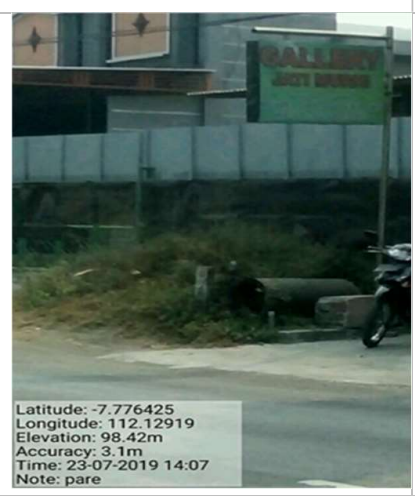

\section{Gambar 21}

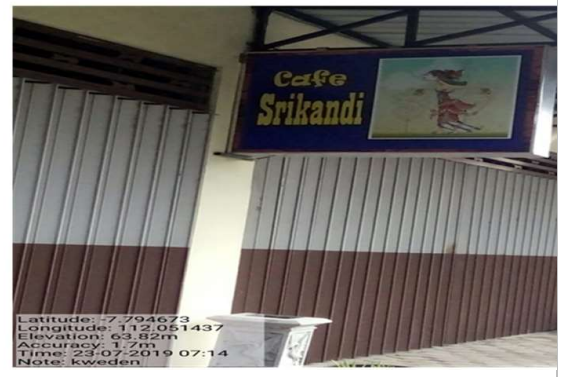

Gambar di atas terletak di Jalan Raya Bendo Pare, sedangkan gambar 21 terletak di Jalan Kweden Kecamatan Ngasem Kabupaten Kediri. Kosakata bahasa Inggris pada papan nama di atas menggunakan struktur frasa Indonesia (DM). Massage, galleri dan Cafe merupakan nomina inti /D/ diterangkan, sedangkan Tradisional, Jati Murni, dan Srikandi berfungsi sebagai $/ \mathrm{M} /$ menerangkan. Tentu saja ini salah karena papan nama di atas 
menggunakan kosakata asing yang berstruktur (MD), sedangkan bahasanya percampuran. Pelaku usaha beranggapan dengan mencantumkan kata bahasa asing akan memberikan dampak mewah dan berkelas, padahal frase tersebut salah. Alternatif pembenarannya adalah pijit tradisional dan galeri Jati Murni atau menggunakan bahasa Inggris secara benar, kemudian menuliskan bahasa Indonesia di atas bahasa asing tersebut, berikut tabel alternatif pembenarannya.

Tabel 7

\begin{tabular}{lll}
\multicolumn{1}{c}{ Papan Nama } & Alternatif Pembenaran \\
\hline Massage Tradisional & Pijat Tradisional & Pijat tradisioanl (Traditional Massage $)$ \\
\hline Gallery Jati Murni & Galeri Jati Murni & Galeri Jati Murni (Murni Gallery) \\
\hline Cafe Srikandi & Kafe Srikandi & Kafe Srikandi (Srikandi Cafe) \\
\hline
\end{tabular}

\section{SIMPULAN}

Berdasarkan penemuan data-data di lapangan dan hasil analisis pada penulisan kesalahan penggunaan bahasa pada iklan media luar ruang di Kabupaten Kediri masih dijumpai beberapa kesalahan yang belum atau tidak sesuai dengan kaidah bahasa Indonesia yang baik dan benar. Bentuk kesalahan tersebut terdiri dari kesalahan ejaan yang meliputi tanda baca, penulisan kata dan kata baku dan tidak baku. Selain itu, kesalahan pada penggunaan bahasa pada iklan media luar ruang di Kabupaten Kediri banyak didominasi dengan ketumpangtindihan penggunaan bahasa Inggris dengan bahasa Indonesia sehingga menyebabkan struktur frasa menjadi kacau. Dengan demikian, Undang-Undang Nomor 24 tahun 2009 belum bisa diterapkan dengan baik.

Untuk meminimalisir kesalahan, pihak pemerintah terutama balai bahasa sedang gencar menggiatkan pengutamaan bahasa Indonesia di media luar ruang. Upaya balai bahasa untuk menggiatkan usaha tersebut dengan mengadakan sosialisasi yang diikuti beberapa lembaga pemerintah, lembaga pendidikan, dan lembaga swasta. Upaya ini pernah dilakukan di Kota Kediri, tetapi belum pernah dilakukan oleh pemerintah Kabupaten Kediri. Ada harapan semoga dengan adanya penelitian ini ada upaya dari pemerintah, terutama pemerintah Kabupaten Kediri agar ada perhatian dalam bidang bahasa misalnya, sosialisasi penggunaan bahasa media luar ruang dengan baik, terutama bagi pelaku usaha komersial. Atau perlombaan tentang penggunaan bahasa yang paling baik dalam badan usaha komersial. Dengan begitu para pelaku usaha dan komersial tidak hanya membuat bahasa yang menarik, tetapi bagaimana peran pelaku usaha tersebut dapat mengangkat pemartabatan bahasa Indonesia.

Selanjutnya untuk meminimalisir kesalahan berbahasa pada bahasa penggunaan media luar ruang khususnya di Kediri, jika memungkinkan perlu dibuatkan peraturan daerah/peraturan Bupati/wali kota tentang pengutamaan bahasa Indonesia dan pelestarian daerah. lembaga perizinan di wilayah kabupaten/kota diharapkan dapat mensyaratkan pengutamaan bahasa Indonesia dalam memberikan penamaan. Usaha-usaha tersebut dilakukan supaya generasi penerus dapat melihat, melestarikan, menerapkan bahasa Indonesia dengan baik. Yang tak kalah penting ada usaha kesadaran dari diri sendiri untuk memulai, menerapkan bahasa sesuai kaidah bahasa Indonesia dengan baik dan benar. 


\section{DAFTAR PUSTAKA}

Alwi, Hasan. 1998. Tata Bahasa Baku Bahasa Indonesia .Jakarta: Balai Pustaka.

Arifin, E Zaenal, 'Implementasi Pasal 36 "Undang-Undang Bahasa”, Pujangga, 1.2 (2015), $1-23$

Badan Pengembangan Dan Pembinaan Bahasa, Kementrian Pendidikan Dan Kebudayaan Republik. Indonesia. Kamus Besar Bahasa Indonesia. Edisi V (on Line)

Balai Bahasa Jawa Timur. Sosialisasi Penggunaan Bahasa Media Luar Ruang Di Kota Kediri, 2019

In, Signage, and T H E District, 'PENYIMPANGAN STRUKTUR FRASA BAHASA INDONESIA'

Miftahudin, Ade, 'Analisis Kesalahan Penggunaan Kata Baku Dalam Pembelajaran Menulis Laporan Perjalanan Siswa Kelas Viii Di Smp Al-Hidayah Lebak Bulus Jakarta', 2014

Rahmadi, Dewi. 2017. Pedoman Umum EBI \& Kesalahan Berbahasa. Solo: GentaSmart.

Setyowati, Nanik. 2010. Analisis Kesalahan Berbabasa Indonesia: Teori Dan Praktik. Surakarta: Yuma Pustaka.

Sudaryanto. 1993. Metode Dan Aneka Teknik Bahasa: Pengantar Penelitian Wahana Kebudayaan Secara Linguistis. Yogyakarta: Duta Wacana University Press.

Susanti, Ratna, and M Pd Penulis, 'Error Analysis of Language in Writing', 2.Penulis 1 (2016)

Sutopo, H.B., 2002. Metodologi Penelitian Kualitatif: Dasar Teori Dan Terapannya Dalam Penelitian. Surakarta: Sebelas Maret University Press.

Tarigan, G. Henry dan Tarigan Djago. 2011. Pengajaran Analisis Kesalahan Berbahasa. Bandung: Angkasa.

Widyatama, Rendra. 2011. Teknik Menulis Naskah Iklan. Jakarta: Cakrawala. 